\title{
DISINFORMASI TERKAIT RIDWAN KAMIL DAN SIKAP PEMILIH PEMULA PADA PEMILIHAN KEPALA DAERAH JAWA BARAT
}

\author{
Heni Nuraeni Zaenudin \\ Fakultas Pendidikan Ilmu Pengetahuan Sosial, Departemen Ilmu Komunikasi, Universitas Pendidikan Indonesia \\ Jl. DR. Setiabudi No. 229, Bandung, Jawa Barat, 40154, Indonesia \\ No. Telp./HP: 081214436831 \\ E-mail: heni.nuraeni@upi.edu
}

Naskah diterima tanggal 2 Januari 2019, direvisi tanggal 1 April 2019, disetujui tanggal 22 April 2019

\section{DISINFORMATION RELATED TO RIDWAN KAMIL AND BEGINNER VOTERS' ATTITUDE ON WEST JAVA REGIONAL HEAD ELECTION}

\begin{abstract}
The phenomenon of disinformation in the context of regional head elections is a big phenomenon in Indonesia. Social media is the target of the most widespread hoax, one of which was in the regional head election in West Java period 2018-2023. The targets of hoax messages were beginner voters and swing voters, considering that most social media users in Indonesia are young people with age range of 15-35 years. The purposes of this study are (1) to determine the effect of exposure to hoax news on social media on perceptions of beginner voters in determining choices in West Java Province regional head elections, (2) to find out how the influential aspects of hoax news on social media affects the perceptions of beginner voters in determining choice in West Java Province regional head elections. The research method used was quantitative explanatory survey. Results indicate that there are effects of hoax news which spread through social media for beginner voters in making choices in the West Java regional head election 2018. However, the effect is not significant. This is because beginner voters tend to see tangible evidence of the success of Rdwan Kamil while in office as Mayor of Bandung.
\end{abstract}

Keywords: disinformation, social media, perception, Jawa Barat regional head election.

\begin{abstract}
Abstrak. Fenomena disinformasi dalam konteks pemilihan kepala daerah menjadi fenomena yang besar di Indonesia. Media sosial menjadi target paling banyak tersebarnya konten yang bersifat disinformasi, salah satunya dalam pilkada (Pemilihan Kepala Daerah) Jawa Barat periode 2018-2023. Sasaran pesan disinformasi yang tersebar merupakan pemilih pemula dan swing voters mengingat pengguna media sosial terbanyak di Indonesia adalah anak muda dengan rentang usia 15-35 tahun. Adapun tujuan penelitian ini yaitu (1) untuk mengetahui pengaruh terpaan disinformasi pada media sosial terhadap persepsi pemilih pemula dalam menetukan pilihan pada Pilakada Jawa Barat, (2) untuk mengetahui bagaimana pengaruh aspek penonjolan konten pesan yang bersifat disinformasi pada media sosial terhadap persepsi pemilih pemula dalam menetukan pilihan pada Pilkada Jawa Barat. Metode penelitian yang digunakan adalah metode penelitian kuantitatif survei eksplanatif. Hasil penelitian menunjukkan adanya pengaruh dari disinformasi yang tersebar melalui media sosial bagi pemilih pemula dalam menentukan pilihan di Pilkada Jawa Barat tahun 2018. Akan tetapi pengaruh yang dihasilkan tidak begitu signifikan. Hal tersebut dikarenakan para pemilih pemula cenderung melihat bukti nyata keberhasilan Ridwan Kamil saat menjabat sebagai Walikota Bandung.
\end{abstract}

Kata kunci: disinformasi, media sosial, persepsi, Pilkada Jawa Barat. 


\section{PENDAHULUAN}

Teknologi komunikasi dan informasi (TIK) berkembang sangat pesat hingga menghadirkan berbagai perubahan dalam berbagai aspek kehidupan manusia. Salah satunya adalah kemudahan akses informasi. Kemudahan akses menjadi fitur yang ditawarkan oleh teknologi komunikasi dan informasi seperti media sosial. Kehadiran media sosial tidak hanya mampu mengubah cara masyarakat dalam mengonsumsi informasi tapi juga pada produksi informasi. Bahkan berbagai informasi di media arus utama juga turut dikonversi dan disebar ulang dalam platform media sosial.

Informasi di internet pada satu sisi mengindikasikan kebebasan berekspresi sebagai hasil dari demokrasi. Kemajuan teknologi membuka ruang bagi setiap jurnalis dan netizen mempublikasikan informasi pada publik. Negara berkembang seperi Tunisia, Pakistan, dan Mesir merupakan beberapa negara yang tidak mau ketinggalan euforia demokrasi dampak dari kehadiran internet. Perkembangan maraknya informasi yang tersebar di internet buah dari hasil demokrasi yang terjadi pada tahun 2007 sampai tahun 2011.

Internet pun pada masa yang akan datang mengubah wajah politik di setiap negara. Konsep ruang publik Jurgen Habbermas disulap menjadi ruang publik digital. Setiap orang memiliki peranan dalam diskusi berkaitan dengan isu politik di ruang publik versi digital. Tersebarnya informasi yang jumlahnya ribuan menghadirkan permasalahan tersendiri. Tantangan masyarakat menghadapi fenomena gempuran informasi dan informasi membuat masyarakat pengguna internet harus bijak dalam menyeleksi informasi.

Mengutip Herring, dkk. dalam Keskenidou et al. (2014), sejak kemunculan internet ditambah dengan kemudahan mengaksesnya, berbagai aspek kehidupan masyarakat berubah secara drastis dan dramatis. Internet juga sering disebut konvergensi media dan media internal. Kemunculan media akses yang berbasis internet kian mempertajam efek media. Internet memiliki kemampuan yang belum ada sebelumnya untuk mengembangkan bentuk baru relasi sosial dan untuk mendeskripsikannya melalui kebaruan interaktivitas.

Istilah hoax news, fake news, informasi sumir, atau disinformasi pun lahir terutama selama pesta politik sedang berlangsung baik dalam ruang lingkup internasional maupun nasional. Beberapa isu informasi bohong dilancarkan di media sosial guna menjatuhkan lawan politik dan menurunkan elektabilitas untuk memilih calon tertentu. Tindakan menurunkan citra di mata pemilih dan disinformasi dilancarkan untuk menguatkan tokoh politik di mata pemilih. Penginformasian palsu adalah usaha untuk menipu atau mengakali pembaca/pendengarnya untuk mempercayai sesuatu padahal sang pencipta informasi palsu tersebut tahu bahwa informasi tersebut adalah palsu.

Sebagai contohnya penyebaran konten yang bersifat disinformasi pada platform Facebook yang mampu mendorong Donald Trump memenangkan pemilihan Presiden Amerika Serikat (Parkinson, 2016). Informasi politik yang tersebar di media sosial diibaratkan seperti puzzle yang harus disusun sesuai validitas data dan informasi. Di Amerika Serikat sendiri murahnya biaya produksi semenjak kehadiran internet mampu mempermudah publikasi informasi. Adanya kemudahan inilah yang disalahgunakan oleh orang-orang yang tidak bertanggungjawab dalam menyebarkan konten yang bersifat disinformasi terkait politik di Amerika.

Pesan yang saling dipertukarkan antara pengguna (pengirim dan penerima) adalah pesan disinformasi dalam bentuk informasi ataupun gambar yang diganti baik kata-kata maupun keterangan gambarnya yang tidak sesuai dengan informasi asli. Produksi konten disinformasi sepenuhnya merupakan kemampuan pengguna baik menciptakan, mengubah, memodifikasi, hingga menyebarkan melalui media sosial. Hal ini turut diperparah dengan kondisi masyarakat Indonesia yang dengan mudah percaya begitu saja dengan informasi yang beredar (Christiany, 2018). Hal ini menunjukkan bahwa informasi atau juga disinformasi 
sangat mudah untuk disebar dan juga dipercaya oleh komunikan.

Disinformasi menjadi salah satu alat baru dalam kontestasi politik dalam platform media sosial untuk saling menjatuhkan atau bahkan meningkatkan elektabilitas para calon. Media sosial menunjukkan bahwa kebebasan berkomunikasi di dunia maya lebih cenderung destruktif daripada bersifat konstruktif yang disebabkan oleh komentar baik berupa ujaran maupun wacana para netizen yang tanpa disertai oleh kesadaran etis (Abdul Malik, 2016). Hal ini menjadi salah satu dampak negatif pada masyarakat yang posisinya sebagai pengguna dan juga sebagai pemilih. Ruang-ruang digital yang seharusnya mampu melengkapi demokrasi justru menjadi pemecah belah antar kelompok pendukung. Adanya kebebasan dalam berkomunikasi memudahkan pula bagi para produsen konten diinformasi dalam memproduksi pesan serta konten yang dapat penyesatkan para pengguna atau komunikator sebagai penerima pesan.

Saat konten disinformasi dimanfaatkan sebagai alat politik guna menjatuhkan lawan atau meningkatkan elektabilitas maka yang pemilih pemula dapat menjadi sasaran dalam menarik suara. Sebagian pemilih pemula masih dipengaruhi ikatan emosional dan komersial dalam menentukan pilihan politiknya. Kecenderungan irasional dari pemilih pemula ini hendaknya dapat dihindari melalui pendidikan politik yang secara intensif dilakukan pemerintah dan partai politik (Sasmita, 2011). Upaya pencegahan serta penanggulangan yang dilakukan partai politik dan pemerintah menjadi salah satu instrumen yang positif dalam melawan penyebaran disinformasi dalam pesta demokrasi. Meskipun dalam praktiknya masih dapat ditemukan oknum-oknum partai politik yang memproduksi serta menyebarkan konten disinformasi ke ruang publik digital.

DailySocialID (2018) terkait Hoax Distribution Through Digital Platforms in Indonesia 2018 menjelaskan, "Facebook, WhatsApp, and Instagram are the most popular platform for respondents to receive information. They are also considered to be the most popular platforms for hoax distribution". Dari presentasenya instagram berada dalam peringkat ke-3 dengan persentase pengguna sebesar 60,24\%. Penggunaan media sosial sebagai alat untuk mengakses berbagai informasi khususnya di Indonesia menjadi salah satu faktor yang mendorong tingginya angka tersebut. Hal ini juga menegasikan bahwa masih banyak masyarakat yang terkena arus disinformasi.

Melalui penelitian ini peneliti mencoba untuk mengetahui apakah fenomena terkait tersebarnya disinformasi melalui media sosial terkait Pilkada Jawa Barat khususnya terkait salah satu calon Gubernur Jawa Barat yakni Ridwan Kamil. Ridwan Kamil adalah Walikota Bandung periode 2013-2018 yang terkenal dengan program kerja membangun taman-taman di Kota Bandung dengan namanama yang unik. Pada dasarnya sebelum dibukanya pendaftaran calon gubernur Jawa Barat dibuka isu disinformasi banyak menimpa tokoh populer menuju calon gubernur Jawa Barat seperti Dedi Mizwar dan Ridwan Kamil. Hal tersebut terjadi karena persaingan yang ketat di wilayah Jawa Barat. Kemudian kedua nama tersebut memiliki rekam jejak dan popularitas yang cukup tinggi. Dibandingkan dengan wilayah lain Jawa Barat merupakan wilayah yang paling paling banyak mendapat sorotan dan juga pasangan calon yang ikut serta. Berdasarkan diskusi-diskusi yang sering terjadi di media massa, Jawa Barat dianggap sebagai barometer dari lumbung suara nasional.

Konten disinformasi menajdi semakin banyak terpublikasi melalui platform media sosial saat menjelang penyelengaraan Pilkada. Dikutip dari situs kominfo.go.id pada tahun 2017 saat digelarnya Pilgub DKI terdapat sepuluh ribu aduan konten yang bersifat suku, agama dan ras dan antargolongan (SARA) serta ujaran kebencian. Kemudian pada tahun 2018 angka aduan masyarakat terkait ujaran kebencian dan konten SARA meningkat pada bulan Februari sejumlah 4.603 aduan menjadi 5.645 aduan di bulan Maret (Hutabarat, 2018). Hal ini mengindikasikan bahwa SARA dan ujaran kebencian menjadi salah satu tren dalam pilkada serentak setelah berbagai peristiwa politik terjadi dalam kontestasi Pilgub DKI. Konten disinformasi yang memiliki sentimen SARA dan ujaran kebencian seolah menjadi 
perangkat atau sarana yang disebarkan secara sengaja melalui jejaring media sosial untuk kepentingan politik.

Platform media sosial menjadi sasaran paling banyak tersebarnya disinformasi terkait pasangan calon gubernur dan wakil gubernur Jawa Barat 2018-2023. Berdasarkan data penetrasi pengguna media berbasis internet berdasarkan usia ada pada angka tertinggi yakni usia 13-18 tahun dengan persentase $75,50 \%$ dan usia 19-34 tahun dengan persentase 74,23\% (APJI, 2017). Jika dilihat dari aspek usia maka target konten disinformasi terkait politik yakni anak muda. Komunikan dalam fenomena ini dapat dikategorikan sebagai pemilih pemula dan swing voters yang secara tidak langsung dapat dipengaruhi presepsinya. Berelson dalam Severin, Werner J. \& Tankard (2009) menyampaikan bahwa proses menerima dan menafsirkan pesan pada kontes komunikasi dikenal istilah penyandian balik (decoding) dengan melibatkan persepsi yang meliputi rangsangan perasaan dan proses informasi.

Berkenaan dengan konsep tersebut peneliti ingin menguji dalam konteks pilkada Jawa Barat di kalangan anak muda. Pada penelitian ini yang menjadi fokus perhatian adalah penyebaran informasi negatif yang menyerang Ridwan Kamil yakni meliputi beberapa isu. Isu yang pertama yakni Ridwan Kamil dianggap sebagai pendukung lesbian, gay, biseksual dan transgender (LGBT) dan penganut Syiah. Informasi tersebut sering menyerang Ridwan Kamil saat dirinya mendeklarasikan diri menjadi Bakal Calon Gubernur Jawa Barat periode 2018-2023.

Pengguna media sosial terbanyak di Indonesia adalah anak muda dengan rentang usia 15-35 tahun. Berdasarkan hal ini peneliti menjadikan mahasiswa baru sebagai objek penelitian, khususnya bagi mahasiswa yang baru pertama kali menggunaan hak suaranya dalam pilkada Jawa Barat 2018. Kemudian peneliti memilih mahasiswa Universitas Pendidikan Indonesia (UPI) Kampus Bumi Siliwangi, didasarkan pada asal mahasiswa yang sebagian besar berasal dari wilayah Jawa Barat. Secara spesifik peneliti menelaah bagaimana pengaruh berita-berita disinformasi di media sosial terhadap sikap pemilih pemula dalam menentukan pilihan pada pilkada Jawa Barat? Kemudian bagaimana pengaruh aspek penonjolan beritaberita disinformasi pada media sosial terhadap persepsi pemilih pemula dalam menetukan pilihan pada pilkada Jawa Barat? Melalui penelitian ini diharapkan peneliti mendapatkan data dari mahasiswa yang berasal dari berbagai kota/kabupaten di Jawa Barat.

\section{LANDASAN KONSEP}

\section{Media Sosial}

Perkembangan teknologi komunikasi mampu mempertemukan individu atau kelompok di arena virtual dalam berkomunikasi yakni komunikasi yang termediasi melalui komputer, telepon genggam, atau perangkat yang terkoneksi dengan internet. Pada dasarnya proses tidak sekedar menjadi media yang memperantai proses distribusi dan sirkulasi pesan, tetapi sebagai medium layaknya aspek serta lingkungan dalam komunikasi tatap muka. Hanya saja komunikasi yang terjadi di media siber lebih banyak tergantuk pada teks, baik teks dalam pengertian sesungguhnya maupun simbol, ikon, atau penanda lain yang mewakili maksud dari pesan (Nashrullah, 2015). Andreas Kaplan dan Michael Haenlein dalam Lesmana (2012) mendefinisikan media sosial sebagai sebuah kelompok aplikasi berbasis internet yang dibangun di atas dasar ideologi dan teknologi web 2.0 dan memungkinkan penciptaan dan pertukaran usergenerated content.

\section{Berita-Berita Disinformasi}

Disinformasi adalah informasi bohong, berdasarkan Kamus Besar Bahasa Indonesia (KBBI) bohong memiliki arti sesuatu yang tidak sesuai dengan keadaan. Disinformasi adalah informasi sesat dan berbahaya karena menyesatkan persepsi manusia dengan menyampaikan informasi palsu sebagai kebenaran (Chen, Yoke yiie, 2014). Menurut Christiany (2018), hoax adalah suatu kata yang digunakan untuk menunjukkan penginformasian palsu atau usaha untuk menipu atau mengakali pembaca untuk mempercayai sesuatu. Penginformasian yang 
tidak berdasarkan kenyataan atau kebenaran (non factual) untuk maksud tertentu. Tujuan berita-berita disinformasi adalah sekadar lelucon, iseng, hingga membentuk opini publik. Intinya berita-berita disinformasi itu sesat dan menyesatkan, apalagi jika pengguna internet tidak kritis dan langsung membagikan informasi yang dibaca kepada pengguna internet lainnya.

\section{Teori S-O-R}

Teori S-O-R yang dikemukakan oleh Hovland, et.al dalam Effendy (2009) sebagai singkatan Stimulus - Organism - Response. Objek materialnya adalah manusia yang jiwanya meliputi komponen-komponen: sikap, opini, perilaku, kognisi afeksi, dan konasi. Menurut teori ini organisme menghasilkan perilaku tertentu jika ada kondisi stimulus khusus, sehingga seseorang dapat mengharapkan dan memperkirakan kesesuaian antara pesan dan reaksi komunikan.

\section{Sikap}

Selanjutnya menurut Mar'at (2001) sikap adalah tingkatan afeksi objek psikologi. Dengan demikian perasaan dalam merespon suatu objek dapat positif yaitu perasaan senang, menerima, terbuka dan lain-lain, sedangkan negatif yaitu perasaan tidak senang, tidak menerima, tidak terbuka, dan lain-lain. Mar'at (2001) juga mengartikan sikap sebagai suatu konstruksi untuk memungkinkan terlihatnya suatu aktivitas.

Sementara Rakhmat (2013) berpendapat bahwa sikap adalah kecenderungan bertindak, berpersepsi, berpikir, dan merasa dalam objek, ide, situasi atau nilai, sikap bukan perilaku tetapi merupakan kecenderungan untuk berperilaku dengan cara-cara tertentu terhadap objek sikap. Dimensi-dimensi yang terdapat dalam sikap yakni meliputi afeksi, kognisi, dan konasi.

\section{Terpaan Media (Media Esposure)}

Terpaan merupakan intensitas khalayak terkena informasi-informasi dari suatu media.
Ardianto dkk (2014) mengungkapkan terpaan dapat diartikan sebagai kegiatan mendengar, melihat, dan membaca pesan-pesan media ataupun mempunyai pengalaman dan perhatian terhadap pesan tersebut yang dapat terjadi pada individu atau kelompok. Terpaan media berusaha mencari data khalayak tentang penggunaan media baik jenis media, frekuensi penggunaan maupun durasi penggunaan. Penggunaan jenis media meliputi media audio, audio visual, media cetak, dan media online. Sementara menurut Rosengren dalam Kriyantono (2009) penggunaan media terdiri dari jumlah waktu yang digunakan dalam berbagai media, jenis isi media, media yang dikonsumsi atau dengan media secara keseluruhan. Dalam hal ini informasi yang dikonsumsi merupakan konten disinformasi terkait Ridwan kamil yang tersebar di media sosial.

\section{Kerangka Pemikiran dan Hipotesis}

Berdasarkan Gambar 1, peneliti menjabarkan operasionalisasi variabel bebas (X) terpaan disinformasi Ridwan Kamil dan variabel terikat (Y) yakni sikap pemilih pemula. Pada variabel bebas (X) terpaan informasi terdapat sub variabel yang terdiri dari frekuensi, durasi, dan atensi. Sedangkan pada variabel terikat $(Y)$ sub variabel yang digunakan meliputi kognisi, afeksi, dan konasi. Gambar 1 menunjukkan gambaran secara konsep dari penelitian ini. Guna membuktikan adanya atau tidak adanya pengaruh terpaan disinformasi Ridwan Kamil terhadap sikap pemilih pemula di kampus Universitas Pendidikan Indonesia Kampus Bumi Siliwangi. Oleh karenanya hipotesis dalam penelitian ini yakni:

Ho = tidak ada pengaruh terpaan konten disinformasi (X) terhadap sikap pemilih pemula (Y).

$\mathrm{Ha}=$ terdapat pengaruh terpaan konten disinformasi $(X)$ terhadap terhadap sikap pemilih pemula $(\mathrm{Y})$. 


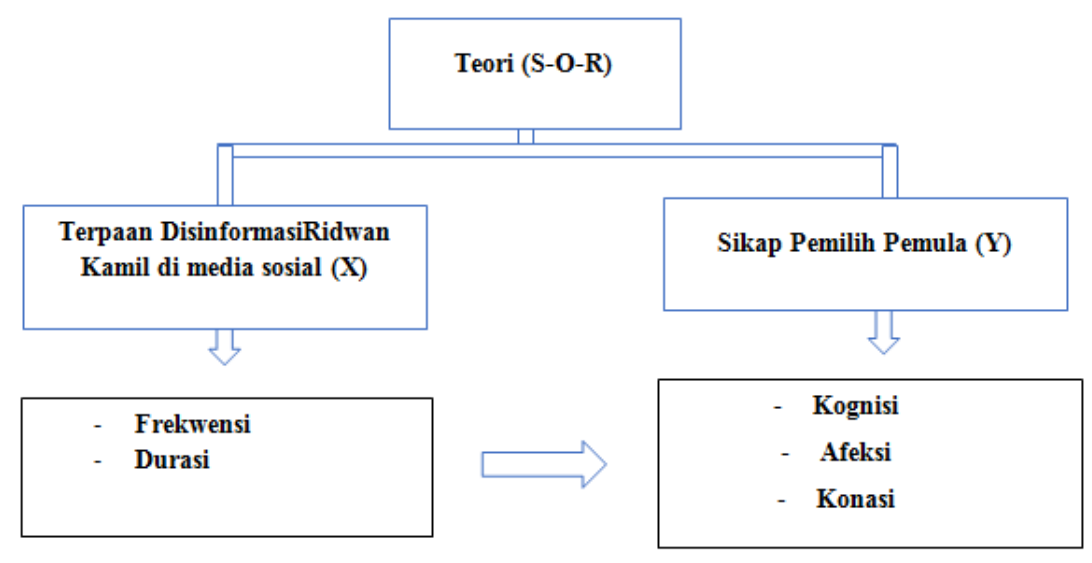

Gambar 1. Kerangka Pemikiran

\section{METODE PENELITIAN}

Metode yang peneliti gunakan adalah metode kuantitatif. Menurut Kriyantono (2009), penelitian kuantitatif menggambarkan atau menjelaskan suatu masalah yang hasilnya dapat digeneralisasikan. Peneliti mementingkan aspek keleluasaan data sehingga data atau hasil penelitian dianggap merupakan representasi dari seluruh populasi. Peneliti dituntut harus bersikap objektif dan memisahkan diri dari data. Membuat batasan masalah yang objektif dengan diuji terlebih dahulu batasan konsep dan alat ukurnya sudah memenuhi prinsip reliabilitas dan validitas.

Pada penelitian ini data utama yang digunakan adalah survei dengan menyebarkan angket. Sebagai sarana pendukung data dalam penelitian ini peneliti melakukan wawancara guna memperkuat data hasil survei atau valid. Selain itu, tujuan peneliti melakukan wawancara adalah agar dapat menggali informasi yang memerlukan pendalaman dengan responden dan juga para ahli.

Pada penelitian ini hanya terdapat dua variabel yakni, variabel bebas (X) terpaan konten disinformasi dan variabel terikat $(\mathrm{Y})$ sikap pemilih pemula. Untuk vaiabel bebas
(X) terpaan konten disinformasi dijabarkan ke dalam beberapa aspek yakni frekuensi, durasi, atensi. Sementara variabel terikat (Y) yakni sikap dijabarkan dari komponen persepsi yaitu komponen kognitif, afektif, dan konatif. Skala dalam penelitian untuk mengukur variabel yaitu skala Likert. Skala Likert dirancang untuk menguji seberapa setuju responden dengan pernyataan dengan skala lima poin. skala Likert yang digunakan untuk mengukur sikap seseorang tentang suatu objek persepsi (Sekaran, 2003). Guna mempermudah dalam memahami penelitian ini berikut adalah tabel operasionalisasi variabel dalam penelitian ini.

Pada penelitian ini, populasinya adalah seluruh mahasiswa Universitas Pendidikan Indonesia yang baru mempunyai pengalaman pertama dalam pemilihan umum khususnya pada pilkada Jawa Barat. Berikut total populasi mahasiswa Universitas Pendidikan Indonesia.

Guna membuat penelitan yang komperhensif pengambilan sampel harus dilakukan sedemikian rupa sehingga diperoleh sampel yang benar-benar dapat mewakili dan dapat menggambarkan keadaan populasi yang sebenarnya, maka dalam penentuan sampel digunakan rumus slovin. 
Tabel 1

Operasionalisasi Variabel

\begin{tabular}{|c|c|c|c|}
\hline Variabel & $\begin{array}{c}\text { Sub } \\
\text { Variabel }\end{array}$ & Indikator & Skala \\
\hline \multirow[t]{3}{*}{$\begin{array}{l}\text { Terpaan Konten Disinformasi } \\
\text { (X) }\end{array}$} & Frekuensi & $\begin{array}{l}\text { Intensitas melihat postingan konten disinformasi } \\
\text { (dalam satu hari) }\end{array}$ & Likert \\
\hline & Durasi & $\begin{array}{l}\text { Lama waktu melihat konten disinformasi } \\
\text { (dalam satu kali frekuensi) }\end{array}$ & Likert \\
\hline & Atensi & Rasa ketertarikan saat melihat konten disinformasi & Likert \\
\hline \multirow[t]{4}{*}{ Sikap Pemilih Pemula (Y) } & Kognisi & $\begin{array}{l}\text { Pengetahuan tentang konten disinformasi terkait Ridwan } \\
\text { Kamil }\end{array}$ & Likert \\
\hline & & $\begin{array}{l}\text { Keyakinan tentang konten disinformasi terkait Ridwan } \\
\text { Kamil }\end{array}$ & Likert \\
\hline & Konasi & Kecenderungan untuk memlih Ridwan Kamil & Likert \\
\hline & Afeksi & $\begin{array}{l}\text { Rasa suka dengan Ridwan Kamil } \\
\text { Rasa tidak suka dengan Ridwan Kamil }\end{array}$ & Likert \\
\hline
\end{tabular}

Tabel 2

Jumlah mahasiswa Universitas Pendidikan Indonesia Kampus Bumi Siliwangi

\begin{tabular}{clc}
\hline No & \multicolumn{1}{c}{ Fakultas } & Frekuensi \\
\hline 1 & FPIS & 1430 \\
2 & FPEB & 588 \\
3 & FPSD & 267 \\
4 & FIP & 930 \\
5 & FPTK & 930 \\
6 & FPOK & 579 \\
7 & FPMIPA & 665 \\
8 & FPBS & 806 \\
& Total & 6195 \\
\hline
\end{tabular}

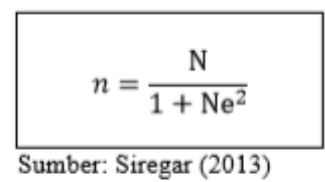

$$
\begin{aligned}
& \text { Keterangan: } \\
& n: \text { Ukuran Sampel } \\
& \mathrm{N}: \text { Ukuran Populasi } \\
& \text { e : Perkiraan tingkat kesalahan }
\end{aligned}
$$

Sumber:(Siregar, 2013)

Pada tahap penarikan sampel, peneliti mengikuti arahan yang dibuat oleh (Arikunto, 2013) bahwa ketika populasi lebih besar dari 100 orang maka pengambilan sampel dapat diambil di antara $10-15 \%$ atau $20-25 \%$. Dalam hal ini peneliti mengambil posisi $10 \%$ maka dengan penghitungan di atas peneliti mendapatkan ukuran sampel sekitar 98 sampel yang diambil dari penelitian ini. Teknik penarikan sampel yang digunakan adalah teknik probability yaitu disproportional stratified random sampling. Hal ini dilakukan guna mempermudah peneliti dalam menentukan responden dalam penelitian ini.

Sumber data utama dalam penelitian ini diambil melalui survei ke beberapa responden dengan menyebarkan kuesioner 
secara langsung. Kuesioner menjadi data utama yang peneliti kumpulkan guna menjawab pertanyaan dalam penelitian ini. pada penelitian ini peneliti menyebarkan kuisioner pada mahasiswa yang masuk dalam kategori pemilih pemula di Universitas Pendidikan Indonesia Kampus Bumi Siliwangi yang terbagi kedalam delapan fakultas mulai dari FPIPS, FPEB,
FPSD, FIP, FPTK, FPOK, FPMIPA, dan FPBS.

Pada penelitian ini juga dilakukan uji validitas menggunakan program SPSS Versi 23.0. Uji reliabilitas dalam penelitian ini menggunakan rumus alpha cronbach. Instrumen dalam penelitian ini dapat dikatakan handal atau fleksibel bila memiliki koefisien realibilitas 0,6 atau lebih. Berikut hasilnya:

Tabel 3

Hasil Uji Reabilitas Variabel (X)

\begin{tabular}{ll}
\hline & Reliability Statistics \\
\hline $\begin{array}{l}\text { Cronbach's } \\
\text { Alpha }\end{array}$ & N of Items \\
\hline, 807 & 23 \\
\hline
\end{tabular}

Tabel 4

Hasil Uji Reabilitas Variabel (Y) Reliability Statistics

\begin{tabular}{ll} 
& Reliability Statistics \\
\hline $\begin{array}{l}\text { Cronbach's } \\
\text { Alpha }\end{array}$ & N of Items \\
\hline, 841 & 12 \\
\hline
\end{tabular}

Berdasarkan hasil uji reliabilitas tabel di atas menunjukkan bahwa variabel terpaan konten disinformasi (X) dengan koefisien alpha sebesar 0,807 dan variabel sikap pemilih pemula (Y) dengan koefisien alpha sebesar 0,841 dapat dinyatakan reliabel. Hal ini didasarkan pada angka koefisien alpha berada di atas angka (0,60). Maka berdasarkan uji reliabilitas pada uji instrument pada seluruh variabel dalam penelitian ini dapat dikatakan andal dan lulus uji.

\section{HASIL PENELITIAN DAN PEMBAHASAN}

Pada era digital atau internet saat ini mampu merubah wajah politik di setiap negara. Ruang publik gubahan Jurgen Habbermas disulap menjadi ruang publik digital. Setiap orang memiliki peranan untuk berdiskusi berkaitan dengan isu politik di ruang publik versi digital. Tersebarnya informasi yang jumlahnya ribuan menghadirkan permasalahan tersendiri. Tantangan masyarakat menghadapi fenomena gempuran informasi membuat masyarakat pengguna internet harus bijak dalam menyeleksi informasi.

Hal ini juga telah masuk ke negara Indonesia dimana aktivitas kampanye, isu hingga penginformasian seputar dunia politik tidak lagi bergerak di ruang-ruang publik seperti lapangan hingga media massa. Namun saat ini telah bergerak di ruang lingkup dunia digital. Menjelang pilkada atau pemilihan ketua daerah pada tahun 2018 di berbagai wilayah di Indonesia, salah satu yang paling menjadi sorotan adalah Jawa Barat. Jawa Barat sangat menjadi sorotan media massa mengingat pada tahun 2019 diselenggarakan perta demokrasi yakni pemilihan umum, dan wilayah Jawa Barat dijadikan barometer untuk mengukur keberhasilan partai-partai dalam memenangkan pemilihan umum. Disinformasi yang tersebar saat Pilkada Jawa Barat banyak yang menyerang pasangan calon nomor satu yakni Ridwan Kamil \& UU Ruzhanul Ulum, terutama Ridwan Kamil. Penginformasian negatif tentang Ridwan Kamil banyak tersebar di media sosial hal tersebut terjadi karena Ridwan Kamil adalah kandidat yang paling 
kuat dalam Pilgub Jawa Barat 2018 untuk menang.

Konten disinformasi terkait Ridwan Kamil banyak tersebar di media sosial, yang pada dasarnya media sosial merupakan platform yang banyak digunakan oleh anak muda. Maka bukan tidak mungkin jika konten disinformasi yang bertebaran di media sosial dapat memengaruhi presepsi para pemilih pemula dalam menentukan calon gubernur dan wakil gubernur pilihannya. Tan, Steven M. Chaffee dalam (Rakhmat, 2012) mengungkapkan bahwa jenis perubahan yang terjadi pada diri khalayak komunikasi massa adalah perubahan perasaan atau sikap dan tingkah laku, atau dengan istilah lain perubahan efek kognitif, afektif, dan behavioral. Media sosial menjadi sarana pembentuk opini publik baru yang mulai banyak digunakan. Hal ini lah yang mendorong banyak para politisi atau calon pejabat publik menggunakan media sosial sebagai sarana kampanye politik.

Isu SARA menjadi sorotan di media arus utama sejak pemilihan gubernur DKI
Jakarta tahun 2017 dan memberikan dampak yang signifikan pada pilkada serentak tahun 2018. Isu SARA menjadi komoditas politik dalam jual beli serangan antara para calon pemimpin daerah. Pada penelitian ini media sosial yang menjadi scope atau cakupan yakni Instagram, Facebook, Twitter, dan juga Youtube. Berdasarkan keempat platform tersebut konten disinformasi terkait Ridwan Kamil yang tersebar di media sosial terbagi kedalam beberapa aspek yakni terkait isu suku, agama, ras, dan antargolongan (SARA).

Pada penelitian ini variabel $(\mathrm{x})$ yakni terpaan konten disinformasi terkait Ridwan Kamil di platform media sosial, dan sikap pemilih pemula sebagai variabel (y) mengingat bahwa peneliti ingin melihat bagaimana pengaruh terpaan disinformasi terhadap pemilih pemula dalam pemilihan gubernur dan wakil gubernur Jawa Barat. Hasil penelitian menunjukan distribusi pemilih pemula berdasarkan jenis kelamin menunjukan $54.09 \%$ di dominasi oleh pemilih pemula dengan gender wanita. Dapat dilihat pada Tabel 5.

Tabel 5

Jenis Kelamin Responden Penelitian

\begin{tabular}{clcc}
\hline No & Jenis Kelamin & Frekuensi & Persentase \\
\hline 1 & Laki-laki & 53 & 54.09 \\
2 & Perempuan & 45 & 45.91 \\
& Total & 98 & $100 \%$ \\
\hline
\end{tabular}

Pada variabel $\mathrm{x}$ dalam penelitian ini yakni terpaan konten disinformasi terkait Ridwan Kamil di platform media sosial terbagi ke dalam tiga indikator yaitu frekuensi, durasi, atensi. Pada pada indikator frekuensi, pernyataan sangat setuju (SS) mendapatkan pernyataan skor cukup dominan yakni $43,7 \%$ yang terdapat pada pertanyaan nomor tiga. Hal ini menunjukkan para pemilih pemula dalam satu hari kerap melihat postingan konten disinformasi terkait Ridwan Kamil. Pada pertanyaan nomor sembilan terkait indikator durasi $44,7 \%$ responden menjawab setuju (S). Hal ini menunjukkan responden melihat konten disinformasi terkait Ridwan Kamil dalam waktu yang singkat dengan waktu kurang dari dua menit pada setiap informasi. Sedangkan pada indikator atensi, kognisi, dan konasi sebagian besar pertanyaan mendapatkan persentase besar dengan pernyataan tidak setuju (TS) dan sangat tidak setuju (STS). Jika dilihat dari indikator frekuensi dan durasi dapat menjelaskan meski durasi waktu melihat konten disinformasi terkait Ridwan Kamil sangat singkat akan tetapi para pemilih pemula melihat dengan frekuensi yang cukup banyak. Seluruh penyebaran konten disinformasi terkait Ridwan Kamil yang menyangkut isu suku, ras, dan agama (SARA) dalam penelitian ini mencakup pada empat platform media sosial yakni Youtube, Facebook, Twitter, dan Instagram. (Gambar 2).

Pada Gambar 2, memperlihatkan asal konten-konten disinformasi terkait Ridwan Kamil yang tersebar dari empat platform 
yang menjadi cakupan dalam penelitian ini. Berdasarkan hasil penghitungan kuesioner yang disebarkan kepada 98 responden dengan kategori yang telah ditentukan sebelumnya menunjukkan angka yang cukup besar dari penyebaran konten disinformasi terkait Ridwan Kamil. Hasilnya menunjukkan responden lebih banyak melihat konten-konten negatif terkait Ridwan Kamil melalui aplikasi media sosial Instagram dengan angka persentase sebesar $53,47 \%$. Kemudian diikuti oleh aplikasi Facebook sebanyak 26,1\%, Twitter 13,4\%, dan Youtube sebanyak 7,03\%. Hal ini menegasikan bahwa konten disinformasi terkait Ridwan Kamil banyak tersebar dan sering muncul pada aplikasi Instagram. Hal ini menandakan perlu adanya kewaspadaan terkait penyebaran informasi melalui media sosial khususnya Instagram. Guna menyikapi penyebaran konten disinformasi di platform media sosial, para pengguna atau user tentunya paling tidak harus bersikap kritis dan skeptis para pengguna platform media sosial agar tidak disesatkan oleh berbagai konten informasi tersebar secara bebas. Salah satu bentuk tindakan skeptis bagi para pengguna media sosial yakni dengan mencari fakta atau kebenaran melalui media massa atau media online yang terverifikasi. Hal ini didasarkan pada konten informasi yang tersebar pada media yang terverifikasi dapat dipertanggungjawabkan kebenarannya. Jika dibandingkan dengan konten informasi yang tersebar di media sosial sangat sulit untuk dikonfirmasi bahkan untuk dipercayai kebenarannya.

Pada variabel y dalam penelitian ini yakni sikap pemilih pemula terbagi ke dalam tiga indikator yakni kognisi, konasi, afeksi. Pada pertanyaaan dengan indikator afeksi yang terdapat dalam pertanyaan nomor sembilan mendapatkan angka tertinggi yakni tidak setuju (TS) dengan persentase sebesar $41,7 \%$. Hal ini menunjukkan bahwa para pemilih pemula cenderung menyukai Ridwan Kamil meskipun banyak informasi negatif tentang Ridwan Kamil di media sosial. Hal ini yang menjadi menarik untuk digali ketika banyaknya infromasi negatif yang menyerang Ridwan Kamil tapi para pemilih pemula tetap menyukai Ridwan Kamil.

Berdasarkan kelompok usia responden yang terdapat dalam Tabel 6, menunjukkan sebaran frekuensi sebanyak empat orang mahasiswa berusia 17 tahun, kemudian 56 responden berusia 18 tahun, 32 responden berusia 19 tahun, dan enam responden berusian 20 tahun. Berdasarkan data usia di atas seluruh responden tergolong kedalam kategori pemilih pemula dalam pilkada. Dalam Undang-Undang No. 10 Tahun 2008 tentang Pemilihan Umum disebutkan bahwa pemilih pemula adalah mereka yang baru pertama kali memilih dan telah berusia 17 tahun atau lebih atau sudah pemah menikah mempunyai hak memilih dalam pemilihan umum dan pemilihan kepala daerah. Mengingat pelaksanaan pilkada diselenggarakan lima tahun sekali maka responden dengan usia 20 tahun pun memungkinkan masuk dalam kategori responden dalam penelitian ini, yakni kategori pemilih pemula. Seluruh responden dalam penelitian ini adalah mahasiswa baru di Universitas Pendidikan Indonesia angkatan 2018.

Data penelitian yang telah terhimpun kemudian diolah dan dilakukan berbagai pengujian. Pada pengujian korelasi dalam penelitian menghasilkan angka pearson corelation sebesar 0,123 . Hal ini menunjukkan tidak adanya korelasi antara variabel $\mathrm{X}$ dan $\mathrm{Y}$ dalam penelitian ini. Selanjutnya dilaksanakan analisis regresi, guna mengetahui hipotesis mana dalam penelitian ini yang diterima atau pun ditolak. Koefisien determinasi ini digunakan untuk mengetahui seberapa besar pengaruh variabel bebas atau $(\mathrm{X})$ dalam penelitian ini memiliki pengaruh terhadap variabel terikatnya atau (Y) dalam penelitian ini. Tabel 7 hasil analisisnya.

Berdasarkan hasil penghitungan dengan menggunakan program SPSS menunjukkan bahwa koefisien determinasi ( $R$-Square) yang diperoleh sebesar 0,015. Maka hasil ini menunjukkan bahwa 1,5\% sikap pemilih pemula dapat dijelaskan oleh terpaan konten disinformasi terkait Ridwan Kamil. Akan tetapi sisanya 99,5\% sikap pemilih pemula dipengaruhi oleh faktor lain 
yang tidak terdapat dalam instrumen

dihasilkan angka Tabel 8.

penelitian ini. Pada hasil pengujian hipotesis

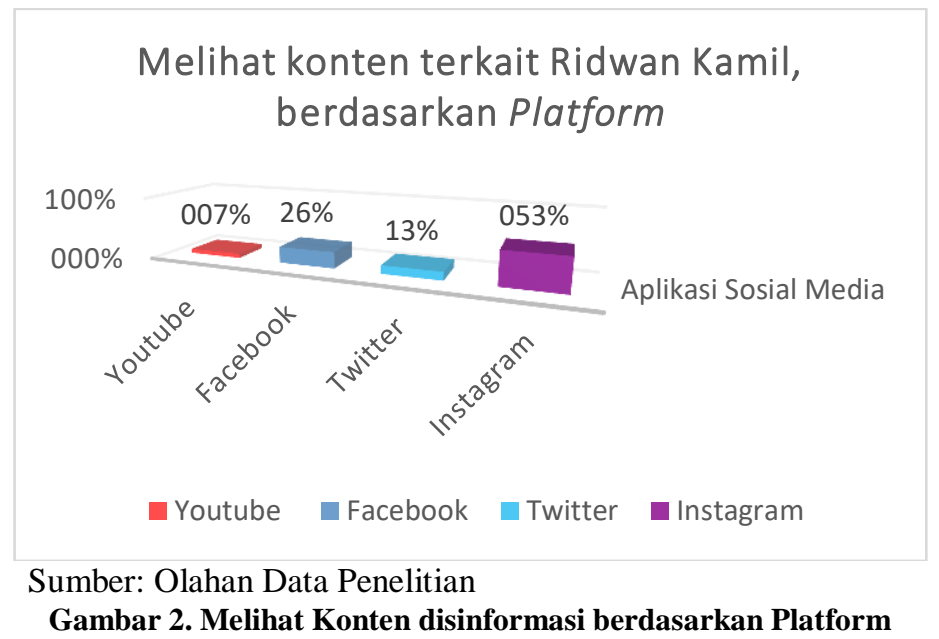

Tabel 6

Usia Responden Penelitian

\begin{tabular}{|c|c|c|c|}
\hline No & Jenis Kelamin & Frekuensi & Persentase \\
\hline 1 & 17 Tahun & 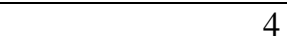 & 4,08 \\
\hline 2 & 18 Tahun & 56 & 57,15 \\
\hline 3 & 19 Tahun & 32 & 32,65 \\
\hline 4 & 20 Tahun & 6 & 6,12 \\
\hline & Total & 98 & $100 \%$ \\
\hline
\end{tabular}

Tabel 7

Analisi Regresi

\begin{tabular}{lclcc}
\hline Model & $\mathbf{R}$ & $\boldsymbol{R}$ Square & $\begin{array}{c}\text { Adjusted } \boldsymbol{R} \\
\text { Square }\end{array}$ & $\begin{array}{c}\text { Std. Error of the } \\
\text { Estimate }\end{array}$ \\
\hline 1 & $.123^{\mathrm{a}}$ & .015 & .005 & 2.70007 \\
\hline
\end{tabular}

Tabel 8

Uji - t

\begin{tabular}{lccccc}
\hline \multirow{2}{*}{ Model } & $\begin{array}{c}\text { Understandardized } \\
\text { Coefficients }\end{array}$ & $\begin{array}{c}\text { Standarized } \\
\text { Coefficients }\end{array}$ & t & \multirow{2}{*}{ Sig. } \\
\cline { 2 - 5 } & $\mathbf{B}$ & Std. Error & Beta & & \\
\hline Constant & 24.130 & 5.052 & & 4.777 & .000 \\
Terpaan konten disinformasi & .093 & .076 & .123 & 1.124 & .228 \\
\hline
\end{tabular}

Berdasarkan tabel di atas dapat dapat dijabarkan hipotesis mana yang diterima dan ditolak. Hasil penghitungan dengan program SPSS menunjukkan bahwa Ho diterima, sehingga Ha ditolak dalam hasil penelitian ini. Pengambilan keputusan hipotesis ini didasarkan pada angkat $t$ hitung tidak lebih besar dari pada t tabel. Angka t hitung sebesar 1.124 < dari pada $t$ tabel 1.661, maka tidak ada pengaruh terpaan konten disinformasi $(X)$ terhadap sikap pemilih pemula (Y).
Hal ini dapat menjelaskan bahwa secara tidak langsung konten disinformasi terkait Ridwan Kamil tidak secara signifikan memengaruhi sikap para pemilih pemula. Pada konteks pemilihan umum, pemilihan kepala daerah, atau pemilihan legislatif pada hakikatnya para pemilih memiliki kriteria sendiri atas pilihannya. Mengingat pada saat individu menentukan pilihan maka banyak faktor yang melatarbelakangi keputusannya dalam memlih. Dalam memilih calon legislatif, kaum pemilih pemula ini cenderung 
memilih figur yang terkenal meskipun mereka tahu lebih lanjut tentang latar belakang dan visi misi caleg tersebut (Yustiningrum \& Ichwanuddin, 2015). Penelitian Yustiningrum dan Ichwanuddin menegaskan bahwa para pemilih pemula cenderung memilih berdasarkan popularitas sang calon.

Hasil penghitungan yang terdapat pada Tabel 8 merupakan data penelitian, dan data penelitian merupakan sebuah manifestasi dalam sebuah penelitian. Dalam hasil penghitungan regresi menunjukan $99,5 \%$ sikap pemilih pemula dipengaruhi oleh faktor lain yang tidak dalam instrumen penelitian ini. Hal ini dapat menegasikan bahwa dalam hasil penelitian ini memungkinkan adanya faktor lain yang menjadi dasar para pemilih pemula tidak mengubah sikapnya pada Ridwan Kamil dalam pemilihan gubernur Jawa Barat 2018-2023. Maka peneliti menggunakan hasil penghitungan data secara kuantitatif sebagai dasar guna menjelaskan hipotesis nol (Ho) diterima. Guna menindaklanjuti data yang telah terhimpun peneliti mencoba menggali informasi pada responeden yang memiliki kecenderungan tidak terpengaruh dengan konten disinformasi terkait Ridwan Kamil.

\section{Afektif}

Rakhmat (2013) mengungkapkan afektif adalah sesuatu yang berhubungan dengan emosi dan sikap penilaian seseorang terhadap sesuatu. Respon ini timbul ketika ada perubahan pada apa yang disenangi dan atau tidak senangi khalayak atas sesuatu. Maka secara singkat afektif merupakan indikator dari sikap yang berkaitan dengan emosi. Pada konteks penelitian ini indikator afektif merujuk pada rasa suka atau pun rasa tidak suka pada Ridwan Kamil setelah melihat beragam postingan konten disinformasi.

Pada salah satu pertanyaan dalam indikator afektif yagn terdapat pada butir pertanyaan ketiga frekuensi data menunjukkan $42,7 \%$ responden menjawab tidak setuju (TS). Hal ini menjelaskan meski responden melihat konten disinformasi terkait Ridwan Kamil, mereka tetap mengikuti akun media sosial Ridwan Kamil. Guna menjelaskan alasan ilmiah pada indikator afektif peneliti melanjutkan wawancara dengan beberapa mahasiswa baru yang menjadi responden dalam penelitian ini.

Hasil wawancara dengan tiga orang mahasiswa dengan kategori pemilih pemula menghasilkan beberapa tanggapan. Pada bagian afektif, mahasiswa para pemilih pemula memandang bahwa program Ridwan Kamil sangat nyata dan terasa saat memimpin Kota Bandung. Sehingga menimbulkan rasa suka terhadap cara kerja Ridwan Kamil sebagai pemimpin. Pemilih pemula cenderung melihat program kerja yang sifatnya fisik dan terasa oleh diri mereka sendiri.

"Buat saya pemimpin yang benar-benar mengabdi ke rakyat itu ya pemimpin yang kerjanya nyata biar banyak informasi yang menjelekkan Ridwan Kamil saya tetap suka cara dia bekerja. Jadi saya suka sama pemimpin yang kerja nyata (wawancara dengan TA pada 12/9/2018)”.

Berdasarkan hasil wawancara pada aspek afektif yang menjadi faktor lain diluar instrumen adalah kriteria pemimpin bagi para pemilih pemula. Pemilih pemula memiliki preferensinya tersendiri dalam menentukan calon pemimpin yang diinginkannya. Hal yang menjadi pendorong afektif untuk tetap menyukai Ridwan Kamil meskipun sering melihat konten disinformasi di media sosial.

\section{Kognitif}

Kognitif merupakan sebuah respon seseorang mengenai sesuatu yang memiliki kaitan dengan pengetahuan, keterampilan, serta informasi. Respon ini dapat ditunjukkan dengan adanya perubahan yang dipahami dirinya (Rakhmat, 2012). Maka dapat dipersingkat indikator kognitif merupakan bentuk respon perubahan yang memiliki kaitan dengan pengetahuan seseorang. Dalam konteks penelitian ini pada indikator kognitif merujuk pada perubahan pandangan terhadap Ridwan Kamil setelah melihat postingan media sosial terkait konten disinformasi.

Pada variabel (Y) dalam indikator kognitif terdapat dalam butir pertanyaan nomor delapan yang menunjukan persentase frekuensi sebesar $61.2 \%$ menjawab tidak setuju (TS). Hal ini menujukkan bahwa 
sebagian besar responden dalam penelitian ini tidak percaya dengan isu terkait SARA yang menyerang Ridwan Kamil. Maka hal ini menunjukkan terdapat faktor lain yang memengaruhi aspek kognitif.

Pada aspek kognitif pemilih pemula menganggap ciri pemimpin yang baik bagii masyarakat adalah pimpinan yang terlihat kerja nyatanya. Hal ini yang menjadikan terpaan disinformasi di media sosial tidak berpengaruh secara sigifikan pada aspek kognitif para mahasiswa pemilih pemula. Persepsi pemimpin idaman bagi pemilih pemula dilihat dari program kerja yang dapat dilihat secara fisik dan terasa oleh mayarakat.

Berdasarkan hasil wawancara dengan responden dalam penelitian ini menunjukkan bahwa responden memiliki rasa tidak percaya terhadap informasi yang didapatnya. Responden tidak meyakini kebenaran konten disinformasi terkait Ridwan Kamil yang menyangkut isu SARA. Sehingga faktor lain yang menjadi pendorong pemilih pemula aspek kognitifnya tidak terpengaruh adalah adanya rasa ketidakpercayaan dan kritis terhadap informasi yang tersebar.

\section{Konasi}

Konasi adalah sebuah respon yang berhubungan dengan sebuah tindakan atau perilaku nyata seseorang (Rakhmat, 2012). Respon ini ditunjukkan dengan sebuah kecenderungan seseorang untuk bertindak terhadap suatu objek yang dikehendakinya. Pada konteks penelitian ini konasi merujuk pada kecenderungan tindakan untuk memilih Ridwan Kamil. Pada salah satu butir pertanyaan dalam angket penelitian yakni nomor 11 responden menjawab tidak setuju (TS) dengan persentase sebesar 46,6\%. Hal ini menunjukkan bahwa responden memiliki kecenderungan untuk memilih Ridwan Kamil dalam pemilihan gubernur Jawa Barat.

Pada aspek konasi saat menerima terpaan disinformasi terkait Ridwan Kamil para pemilih pemula lebih cenderung membiarkan atau mengabaikan konten disinformasi yang beredar di media sosial. Meski telah mendapatkan terpaan disinformasi pemilih pemula tidak memiliki kecenderungan untuk memilih pasangan calon lain dalam pemilihan gubernur Jawa
Barat 2018. Oleh karenanya pengaruhnya tidak begitu signifikan.

Berdasarkan hasil wawancara dapat dijelaskan, bahwa adanya faktor yang menjadi dasar bagi para pemilih pemula untuk tidak terpengaruh dengan penyebaran konten disinformasi terkait Ridwan kamil di media sosial. Faktor itu adalah karakteristik atau kriteria calon pemimpin dari para pemilih pemula di Universitas Pendidikan Indonesia adalah pemimpin yang memiliki ketenaran dan memiliki kerja yang nyata. Dalam hal ini para pemilih pemula menganggap Ridwan Kamil adalah sosok pemimpin yang mengabdi dan kerjanya jelas. Hal tersebut terbukti saat Ridwan Kamil memimpin Kota Bandung sebagai Walikota periode 2015-2018.

\section{PENUTUP}

\section{Simpulan}

Tidak ada pengaruh dari terpaan konten disinformasi terkait Ridwan Kamil yang tersebar di media sosial terhadap sikap mahasiswa Universitas Pendidikan Indonesia sebagai pemilih pemula dalam Pilkada Jawa Barat 2018. Berdasarkan hasil penelitian lanjutan dengan melakukan wawancara dengan beberapa responden menunjukkan bahwa terdapat faktor lain yang menjadi pendorong afektif, kognitif, dan konatif pemilih pemula untuk tidak terpengaruh dengan penyebaran konten disinformasi yang menyerang Ridwan Kamil. Faktor lain yang mendorong pemilih pemula untuk tidak terpengaruh dengan konten yang menyerang Ridwan Kamil yakni preferensi dan rasa tidak percaya atau skeptis akan isu yang beredar.

Akan tetapi jika diamati pada variabel $\mathrm{X}$ tekait terpaan, menunjukkan bahwa media sosial sebagai platform yang banyak digunakan masyarakat untuk mengakses informasi banyak tersebar konten disinformasi atau pesan dengan konten disinformasi.

\section{Saran}

Pemerintah perlu mengawasi persebaran konten disinformasi di media sosial. Untuk peneliti yang akan melakukan 
penelitian serupa di masa yang akan datang perlu memperhatikan kekuatan instrumen penelitian. Ada baiknya jika pada penelitian selanjutnya peneliti-peneliti lain lebih menggali informasi yang lebih dalam yakni karakteristik sosok pemimpin bagi mahasiswa pemilih pemula dengan penelitian kualitatif.

\section{DAFTAR PUSTAKA}

Abdul Malik (2016) Agitasi dan Propaganda di Media Sosial (Studi Kasus Cyberwar AntarNetizen terkait Dugaan Penistaan Agama oleh Basuki Tjahaja Purnama). Lontar. 4 (3), 1-15.

APJI (2017) Penetrasi \& Perilaku Pengguna Internet Indonesia. Apjii.2018 (31 August 2018).

Ardianto, Elvinaro, Lukiati Komala, S.K. (2014) Komunikasi Massa: Suatu Pengantar. Bandung, Simbiosa Rekatama.

Arikunto, S. (2013) Prosedur Penelitian: Suatu Pendekatan Praktik. Jakarta, Rineka Cipta.

Chen, Yoke yiie, et all (2014) Email Hoax Detection System Using Levenshtein Distance Methods. Journal of Computers, 9(2). 9 (2).

Christiany, J. (2018) Christiany Juditha. Jurnal Pekommas. 3 (1), 31-44.

dailysocial.id (2018) "Hoax Distribution Through Digital Platforms in Indonesia 2018”.

Effendy, O.U. (2009) Komunikasi Teori dan Praktek. Jakarta, Grasindo Rosdakarya.

Hutabarat, D. (2018) Kementerian Komunikasi dan Informatika. [Online]. 2018. Kementerian Komunikasi dan Informatika. Available from: https://kominfo.go.id/content/detail/8949/ini -cara-mengatasi-berita-hoax-di-duniamaya/0/sorotan_media [Accessed: 25 March 2019].

Keskenidou, M., Kyridis, A., Valsamidou, L.P. \& Soulani, A.H. (2014) The Internet as a source of information. the social role of blogs and their reliability. Observatorio. 8 (1), 203-228.

Kriyantono, R. (2009) Teknik Praktis Riset Komunikasi. Jakarta, Predana Media Group.

Lesmana, Ig.N.A. (2012) Analisis Pengaruh Media Sosial Twitter Terhadap Pembentukan Brand Attachment. Universitas Indonesia.

Mar'at (2001) Sikap Manusia: Perubahan serta pengukuranya. Bandung, Ghalia Indonesia.

Nashrullah, R. (2015) Media Sosial Prespektif 60
Komunikasi, Budaya, dan Teknologi. bandung, Simbiosa Rekatama.

Parkinson, H.J. (2016) Click and elect: how fake news helped Donald Trump win a real election. 2016.

Rakhmat, J. (2012) Psikologi Komunikasi. Bandung., Remaja Rosdakarya.

Sasmita, S. (2011) Peran Informasi Politik Terhadap Partisipasi Pemilih Pemula Dalam Pemilu/Pemilukada. Jurnal Ilmiah Administrasi Publik dan Pembangunan. 2 (1), 217-224.

Sekaran, U. (2003) Research Methods For Bussiness '4' ^" $t h$ " Ed. United Kingdom, Wiley Publication.

Severin, Werner J. \& Tankard, J.W. (2009) Teori Komunikasi: Sejarah, Metode, dan Terpaan di dalam Media Massa. Jakarta, Prenada Media Group.

Siregar, S. (2013) Metode Penelitian Kuantitatif. Jakarta, PT Fajar Interpratama Mandiri.

Yustiningrum, R.E. \& Ichwanuddin, W. (2015) Political Participation and Voting Behavior in General Election 2014. Jurnal Penelitian Politik. 12 (1), 117-135. 